Check for updates

Cite this: RSC Adv., 2017, 7, 27415

Received 27th March 2017

Accepted 17th May 2017

DOI: $10.1039 / \mathrm{c} 7 \mathrm{ra03523c}$

rsc.li/rsc-advances

\section{Phase evolution and microwave dielectric properties of ceramics with nominal composition $\mathrm{Li}_{2 x}\left(\mathrm{Zn}_{0.95} \mathrm{Co}_{0.05}\right)_{2-x} \mathrm{SiO}_{4}$ for LTCC applications}

\author{
Xiangyu Du, ${ }^{a}$ Hua Su, (D) *ab Huaiwu Zhang, ${ }^{a}$ Xiuting Liu $^{a}$ and Xiaoli Tang ${ }^{a}$
}

$\mathrm{Li}_{2 x}\left(\mathrm{Zn}_{0.95} \mathrm{CO}_{0.05}\right)_{2-x} \mathrm{SiO}_{4}(0 \leq x \leq 1)$ ceramics were prepared through the conventional solid-state route. A fixed amount of $\mathrm{Li}_{2} \mathrm{O}-\mathrm{MgO}-\mathrm{ZnO}-\mathrm{B}_{2} \mathrm{O}_{3}-\mathrm{SiO}_{2}$ (LMZBS) glass was used as a sintering aid to help lower the sintering temperature to around $900{ }^{\circ} \mathrm{C}$. The effects of part lithium-ion substitution on the phase formation, sintering behaviour, microstructures and microwave dielectric properties of the ceramics were systematically investigated. When $x=0.25$, the sample achieved a dense microstructure and exhibited excellent microwave dielectric properties of $\varepsilon_{\mathrm{r}}=6.47, Q \times f=131579 \mathrm{GHz}$ and $\tau_{\mathrm{f}}=$ $-27.12 \mathrm{ppm}{ }^{\circ} \mathrm{C}^{-1}$. For its practical application in low-temperature co-fired ceramics (LTCC), large positive $\tau_{f}$ of $\mathrm{CaTiO}_{3}$ was used to adjust the $\tau_{f}$ value of the composite ceramic to nearly zero. The composite ceramic of $0.975 \mathrm{Li}_{0.5}\left(\mathrm{Zn}_{0.95} \mathrm{CO}_{0.05}\right)_{1.75} \mathrm{SiO}_{4}-0.025 \mathrm{CaTiO} 3$ sintered at $900{ }^{\circ} \mathrm{C}$ also presented good microwave dielectric properties of $\varepsilon_{\mathrm{r}}=6.773, \mathrm{Q} \times f=69177 \mathrm{GHz}$ and $\tau_{\mathrm{f}}=-2.45 \mathrm{ppm}{ }^{\circ} \mathrm{C}^{-1}$.

\section{Introduction}

Microwave dielectric materials are widely investigated for their extensive applications as filters, duplexers and antennas in microwave communication industries., ${ }^{\mathbf{1} 2}$ Materials with low permittivity $\left(\varepsilon_{\mathrm{r}}\right)$, high quality factor $(Q \times f)$ and near-zero temperature coefficient of resonant frequency $\left(\tau_{\mathrm{f}}\right)$ are required to reduce cross-talk, propagation delay time, noise and power dissipation. ${ }^{3-5}$ Furthermore, these materials should be sintered at temperatures lower than $950{ }^{\circ} \mathrm{C}$ or even $900{ }^{\circ} \mathrm{C}$ to be used in LTCC multi-layer devices for the miniaturisation and integration of microwave components because of silver (Ag) electrode (around $961^{\circ} \mathrm{C}$ ), which is typically used as metallic electrode in LTCC materials. ${ }^{6,7}$ Although a number of materials (such as $\mathrm{Al}_{2} \mathrm{O}_{3}$ (ref. 4), $\mathrm{MgTiO}_{3}$ (ref. 8) and $\mathrm{Mg}_{2} \mathrm{SiO}_{4}$ (ref. 3)) have low permittivity and dielectric loss, these materials cannot be used in LTCC multi-layer devices because of the high sintering temperature. ${ }^{9} \mathrm{Zn}_{2} \mathrm{SiO}_{4}$ is one of these materials and has a low dielectric constant (6.6), a high quality factor value (219 000 $\mathrm{GHz}$ ) and a temperature coefficient of resonant frequency of $-61 \mathrm{ppm}{ }^{\circ} \mathrm{C}^{-1}$. Analogously, the high sintering temperature of $1340{ }^{\circ} \mathrm{C}$ limits the application of $\mathrm{Zn}_{2} \mathrm{SiO}_{4}$ in LTCC technology. ${ }^{10}$

Recently, Chen reported that the co-substitution $\left(\mathrm{Zn}_{1-x^{-}}\right.$ $\left.\mathrm{Co}_{x}\right)_{2} \mathrm{SiO}_{4}$ ceramics lowers the sintering temperature of $\mathrm{Zn}_{2} \mathrm{SiO}_{4}$ from $1340{ }^{\circ} \mathrm{C}$ to $1300{ }^{\circ} \mathrm{C}$ and restrains the formation of $\mathrm{ZnO}$

${ }^{a}$ State Key Laboratory of Electronic Thin Films and Integrated Devices, University of Electronic Science and Technology of China, Chengdu 610054, China. E-mail: uestcsh77@163.com

${ }^{b}$ Institute of Electronic and Information Engineering, University of Electronic Science and Technology of China, Dongguan 518105, China phase. ${ }^{11}$ Zhou lowered the sintering temperature of $\left(\mathrm{Zn}_{0.95^{-}}\right.$ $\left.\mathrm{Co}_{0.05}\right)_{2} \mathrm{SiO}_{4}$ ceramics to $900{ }^{\circ} \mathrm{C}$ by adding $1.5 \mathrm{wt} \%$ LBBS glass. The ceramics sintered at $900{ }^{\circ} \mathrm{C}$ showed $\varepsilon_{\mathrm{r}}=6.16, Q \times f=$ $33000 \mathrm{GHz}$ and $\tau_{\mathrm{f}}=-59 \mathrm{ppm}{ }^{\circ} \mathrm{C}^{-1} \cdot{ }^{12}$ Nonetheless, the ceramics have a large negative $\tau_{\mathrm{f}}$ value, which restricts its potential for practical application. Furthermore, the quality factor is still too low to keep up with the high-speed development of LTCC technology. Although the addition of low softening point glass is the most inexpensive way to lower the sintering temperature of dielectric ceramics, previous studies concluded that a large amount of glass addition leads to either high microwave dielectric loss or crack formation. ${ }^{13}$ Hence, new strategies combined with low amount of sintering aids should be developed to further lower the sintering temperature and dielectric loss of $\left(\mathrm{Zn}_{0.95} \mathrm{Co}_{0.05}\right)_{2} \mathrm{SiO}_{4}$ ceramics.

The lithium-substitution on $\mathrm{Li}_{2} \mathrm{CaSiO}_{4}{ }^{14} \mathrm{LiAlSiO}_{4}$ (ref. 15) and $\mathrm{Li}_{2} \mathrm{MgSiO}_{4}$ (ref. 16) ceramics presented good dielectric properties of low dielectric constant $(<10)$ and high $Q \times f$ value. However, the phase evolution, sintering behaviour and optimal lithium-substitution content on $\left(\mathrm{Zn}_{0.95} \mathrm{Co}_{0.05}\right)_{2} \mathrm{SiO}_{4}$ ceramics are not yet reported. Therefore, in this work, the ceramics with nominal composition $\mathrm{Li}_{2 x}\left(\mathrm{Zn}_{0.95} \mathrm{Co}_{0.05}\right)_{2-x} \mathrm{SiO}_{4}$ was synthesised to systematically study the phase formation, sintering behaviour, microstructures and microwave dielectric properties. A fixed amount of LMZBS glass was used as a sintering aid to help lower the sintering temperature at around $900{ }^{\circ} \mathrm{C}$. Moreover, a common modifier with large positive $\tau_{\mathrm{f}}$ of $\mathrm{CaTiO}_{3}$ was used to adjust the $\tau_{\mathrm{f}}$ value of the ceramic, which exhibited the best microwave dielectric property, in the ceramics with nominal composition $\mathrm{Li}_{2 x}\left(\mathrm{Zn}_{0.95} \mathrm{Co}_{0.05}\right)_{2-x} \mathrm{SiO}_{4}$ to nearly zero, thereby 
making these ceramics promising candidates for LTCC materials.

\section{Experimental}

\subsection{Preparation of ceramic samples}

$\mathrm{Li}_{2 x}\left(\mathrm{Zn}_{0.95} \mathrm{Co}_{0.05}\right)_{2-x} \mathrm{SiO}_{4}(0 \leq x \leq 1)$ ceramics were prepared through the traditional solid-state ceramic route. The schematic plot of the fabrication process of ceramics is shown in Fig. 1. A previous study reported that the cobalt ions substituted for zinc ions in the lattice sites of $\mathrm{ZnO}$ exist as $\mathrm{Co}^{2+}$ ions when $\mathrm{Co}_{2} \mathrm{O}_{3}$ was used as raw powders. ${ }^{17}$ Hence, high-purity oxides $\mathrm{Li}_{2} \mathrm{CO}_{3}(99 \%)$, $\mathrm{ZnO}(99 \%), \mathrm{SiO}_{2}$ (99\%), $\mathrm{Co}_{2} \mathrm{O}_{3}(99 \%), \mathrm{CaCO}_{3}$ (99\%) and $\mathrm{TiO}_{2}$ (99\%) were used as the raw materials. These raw powders, which were weighed according to respective stoichiometric ratio of $\mathrm{Li}_{2 x}\left(\mathrm{Zn}_{0.95} \mathrm{Co}_{0.05}\right)_{2-x} \mathrm{SiO}_{4}(0 \leq x \leq 1)$ and $\mathrm{CaTiO}_{3}$, were ballmilled in nylon jars with zirconia balls in distilled water for $6 \mathrm{~h}$. The resultant slurry was dried, sieved and calcined at $1050{ }^{\circ} \mathrm{C}$ for $4 \mathrm{~h}$ and $1100{ }^{\circ} \mathrm{C}$ for $3 \mathrm{~h}$ in air, respectively. A fixed amount of $1.5 \mathrm{wt} \%$ LMZBS glass was doped to the pre-sintered $\mathrm{Li}_{2 x}\left(\mathrm{Zn}_{0.95} \mathrm{Co}_{0.05}\right)_{2-x} \mathrm{SiO}_{4}(0 \leq x \leq 1)$ powders and then re-milled in distilled water medium for $12 \mathrm{~h}$. With $25 \mathrm{wt} \%$ polyvinyl alcohol (PVA) solution as a binder, the powders were dried at $120{ }^{\circ} \mathrm{C}$, well-ground, granulated and pressed into disks under a pressure of $9 \mathrm{MPa}$ and then sintered at $850{ }^{\circ} \mathrm{C}$ to $950{ }^{\circ} \mathrm{C}$ for $3 \mathrm{~h}$.

After determining the optimal $x$ value to obtain the best microwave dielectric properties of $\mathrm{Li}_{2 x}\left(\mathrm{Zn}_{0.95} \mathrm{Co}_{0.05}\right)_{2-x} \mathrm{SiO}_{4}(0 \leq$ $x \leq 1$ ) ceramics sintered at $900{ }^{\circ} \mathrm{C}$, different amounts of presintered $\mathrm{CaTiO}_{3}$ powders were added to $\mathrm{Li}_{2 x}\left(\mathrm{Zn}_{0.95} \mathrm{Co}_{0.05}\right)_{2-x^{-}}$ $\mathrm{SiO}_{4}$ ( $x$ was determined) powders with $1.5 \mathrm{wt} \%$ LMZBS glass to adjust the $\tau_{\mathrm{f}}$ value of $\mathrm{Li}_{2 x}\left(\mathrm{Zn}_{0.95} \mathrm{Co}_{0.05}\right)_{2-x} \mathrm{SiO}_{4}$ ceramic to nearly zero. The subsequent process was similar to the abovementioned procedure.

\subsection{Preparation of glass}

The $\mathrm{Li}_{2} \mathrm{O}-\mathrm{MgO}-\mathrm{ZnO}-\mathrm{B}_{2} \mathrm{O}_{3}-\mathrm{SiO}_{2}$ (LMZBS) glass was synthesised using a quenching method. High-purity grade raw materials (>99\%) were mixed, ball-milled and melted at $1350{ }^{\circ} \mathrm{C}$ for $1 \mathrm{~h}$ using an alumina crucible at the molar ratio of $\mathrm{Li}_{2} \mathrm{CO}_{3}: \mathrm{MgO}: \mathrm{ZnO}: \mathrm{B}_{2} \mathrm{O}_{3}: \mathrm{SiO}_{2}=20: 20: 20: 20: 20$. The solution was quickly removed from the furnace and was quenched with cold distilled water to obtain the glass.

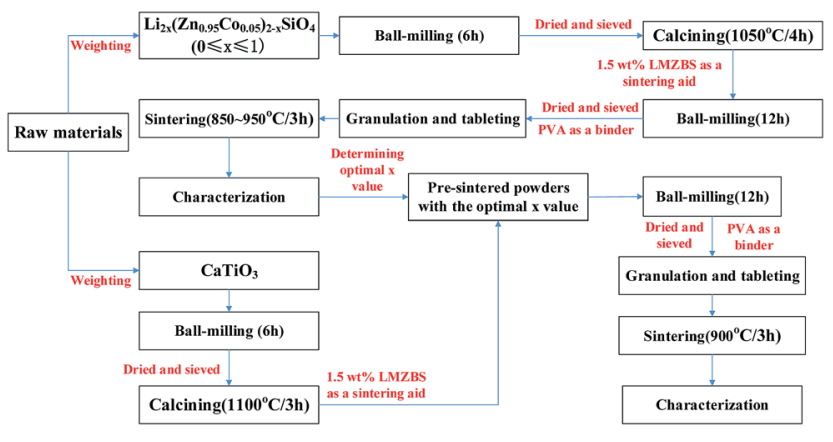

Fig. 1 Schematic plot of the fabrication process of ceramics.

\subsection{Sample characterization}

The bulk densities of these sintered specimens were measured using the Archimedes method. Relative densities were obtained by using the ratio of the bulk and theoretical densities. The phase compositions of theses sintered samples were determined by X-ray diffraction (XRD:DX-2700) using $\mathrm{Cu} \mathrm{K} \alpha$ radiation. The microstructure of the ceramics was examined by scanning electron microscopy (SEM: Hitachi S-3400N). The microwave dielectric properties of the sintered specimens were investigated using an Agilent N5230A network analyser (300 $\mathrm{MHz}$ to $20 \mathrm{GHz}$ ) in a resonant cavity. The quality factor and relative permittivity were measured by the resonant-cavity method and the Hakki-Coleman method, respectively. ${ }^{18}$ The temperature coefficient of resonant frequency $\left(\tau_{\mathrm{f}}\right)$ was measured from the invar cavity using the following formula in the temperature range of $20-80{ }^{\circ} \mathrm{C}:{ }^{19}$

$$
\tau_{\mathrm{f}}=\frac{f_{\mathrm{T}}-f_{0}}{f_{0}\left(T-T_{0}\right)} \times 10^{6}
$$

where $f_{\mathrm{T}}$ and $f_{0}$ are the resonant frequencies at $80{ }^{\circ} \mathrm{C}$ and $20^{\circ} \mathrm{C}$, $T$ and $T_{0}$ are $80^{\circ} \mathrm{C}$ and $20^{\circ} \mathrm{C}$, respectively.

\section{Results and discussion}

Fig. 2a shows the XRD diffraction patterns of $\mathrm{Li}_{2 x}\left(\mathrm{Zn}_{0.95^{-}}\right.$ $\left.\mathrm{Co}_{0.05}\right)_{2-x} \mathrm{SiO}_{4}(0 \leq x \leq 1)$ ceramics doped with $1.5 \mathrm{wt} \%$ LMZBS and sintered at $900{ }^{\circ} \mathrm{C}$ for $3 \mathrm{~h}$ in air. Fig. $2 \mathrm{~b}$ shows the schematic plot of phase evolution of $\mathrm{Li}_{2 x}\left(\mathrm{Zn}_{0.95} \mathrm{Co}_{0.05}\right)_{2-x} \mathrm{SiO}_{4}$ with various amounts of lithium-ion substitution. Only a rhombohedral structure $(\mathrm{Zn}, \mathrm{Co})_{2} \mathrm{SiO}_{4}$ phase $(\odot, \mathrm{PDF} \# 46-1316)$ appeared in the XRD pattern of the sample with no lithium doped. However, when $0.125 \leq x \leq 0.625$, the $\mathrm{Li}_{1.6} \mathrm{Zn}_{1.2} \mathrm{SiO}_{4}$ phase $(\bullet, \mathrm{PDF} \# 24$ 0676) co-existed with $(\mathrm{Zn}, \mathrm{Co})_{2} \mathrm{SiO}_{4}$ phase in the sintered samples. The peak intensities of $\mathrm{Li}_{1.6} \mathrm{Zn}_{1.2} \mathrm{SiO}_{4}$ phase gradually increased with the increasing $x$ value. When $0.125 \leq x \leq 0.375$, the crystalline phase of $(\mathrm{Zn}, \mathrm{Co})_{2} \mathrm{SiO}_{4}$ was the main phase, and the phase of $\mathrm{Li}_{1.6} \mathrm{Zn}_{1.2} \mathrm{SiO}_{4}$ was the minor phase. However, both of the crystalline phases became the main phase when $x$ was increased to 0.5 . When the $x$ value exceeded 0.625 , the phase of $(\mathrm{Zn}, \mathrm{Co})_{2} \mathrm{SiO}_{4}$ disappeared (Fig. $2 \mathrm{a}(\mathrm{g})$ ), and another two crystalline phases of tetragonal structure $\mathrm{Li}_{2} \mathrm{ZnSiO}_{4}$ (*, PDF \#15-0056) and orthorhombic structure $\mathrm{Li}_{2} \mathrm{CoSiO}_{4}$ ( $\nabla$, PDF \#24-0611) appeared in the sintered sample when $x=1$ (Fig. 2a(h)). Fig. 2 shows that various amounts of lithium-ion substitution induce different phase-formations in $\mathrm{Li}_{2 x}\left(\mathrm{Zn}_{0.95} \mathrm{Co}_{0.05}\right)_{2-x} \mathrm{SiO}_{4}(0 \leq x \leq$ 1) ceramics.

Fig. 3 illustrates the SEM images of samples doped with 1.5 wt $\%$ LMZBS glass and sintered at $900{ }^{\circ} \mathrm{C}$ with various $x$ values. Generally, the microstructures present considerable densification that might be due to the sufficient liquid phase, which resulted from the glass addition. In detail, with the increasing $x$ value to 0.25 , the pores decreased, and the grain was enlarged (see Fig. 2a-c). Combined with the XRD patterns shown in Fig. 2a, this finding explained that a moderate amount of $\mathrm{Li}$ substitution might reduce the sintering temperature of the ceramics with nominal composition $\mathrm{Li}_{2 x}\left(\mathrm{Zn}_{0.95} \mathrm{Co}_{0.05}\right)_{2-x} \mathrm{SiO}_{4}$ 


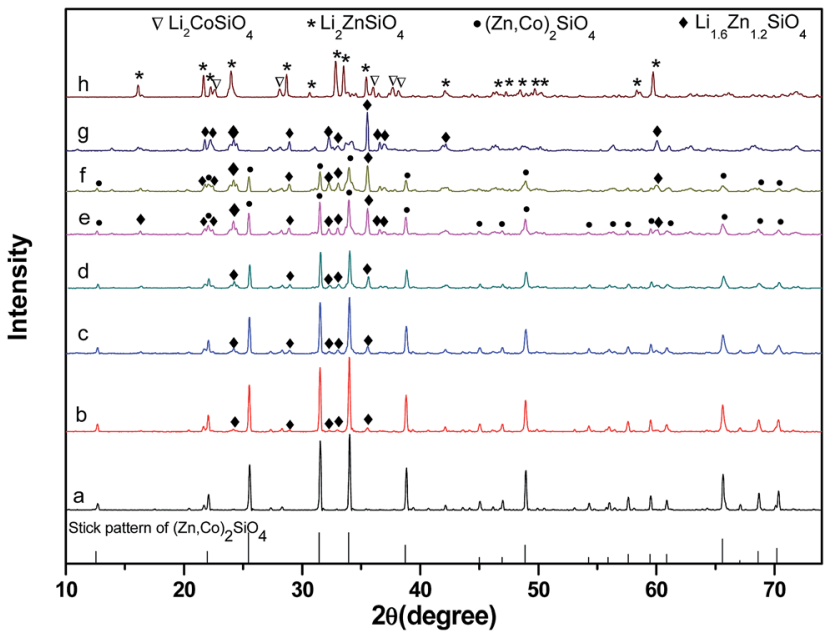

(a)
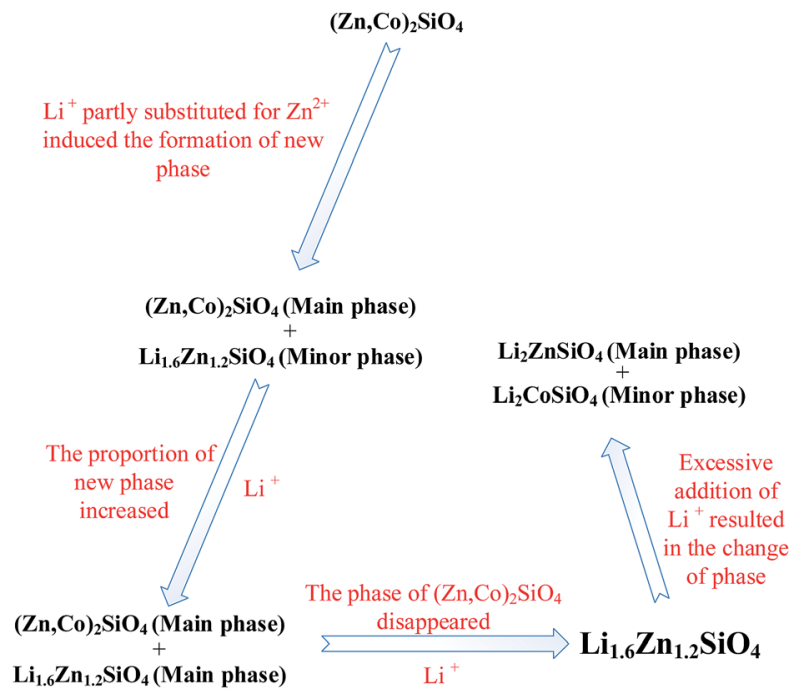

(b)

Fig. 2 (a) XRD diffraction patterns of $\mathrm{Li}_{2 x}\left(\mathrm{Zn}_{0.95} \mathrm{CO}_{0.05}\right)_{2-x} \mathrm{SiO}_{4}(0 \leq x \leq$ 1) ceramics doped with $1.5 \mathrm{wt} \% \mathrm{LMZBS}$ and sintered at $900{ }^{\circ} \mathrm{C}$ for $3 \mathrm{~h}$. (a) $x=0$, (b) $x=0.125$, (c) $x=0.25$, (d) $x=0.375$, (e) $x=0.5$, (f) $x=$ 0.625, (g) $x=0.75$, and (h) $x=1$. (b) Schematic plot of phase evolution of $\mathrm{Li}_{2 x}\left(\mathrm{Zn}_{0.95} \mathrm{CO}_{0.05}\right)_{2-x} \mathrm{SiO}_{4}$ with various amounts of lithium-ion substitution.

via synthesising $\mathrm{Li}_{1.6} \mathrm{Zn}_{1.2} \mathrm{SiO}_{4}$. The sintering temperature of $\left(\mathrm{Zn}_{0.95} \mathrm{Co}_{0.05}\right)_{2} \mathrm{SiO}_{4}$ was $1300{ }^{\circ} \mathrm{C}$, which is almost similar to that of $\mathrm{Zn}_{2} \mathrm{SiO}_{4} \cdot{ }^{10,12}$ It was reported that lithium-ions partly substituted for metal cations significantly reduced the sintering temperature compared with that of initial silicate materials. ${ }^{15,16,20}$ Hence, the sintering temperature of $\mathrm{Li}_{1.6} \mathrm{Zn}_{1.2} \mathrm{SiO}_{4}$ was lower than that of $\left(\mathrm{Zn}_{0.95} \mathrm{Co}_{0.05}\right)_{2} \mathrm{SiO}_{4}$. However, with the successive addition of lithium, the pores increased (Fig. 3d-f), and a large amount of liquid phase (see Fig. 3f) and evident closed pores in the grains (see Fig. 3e) were observed. These phenomena are attributed to the fast growth of the grains; thus, some pores were trapped in the bodies of the abnormal growth grains. ${ }^{21}$ In addition, the liquid phase implied that lithium-ion substitution reduces the sintering temperature and thereby

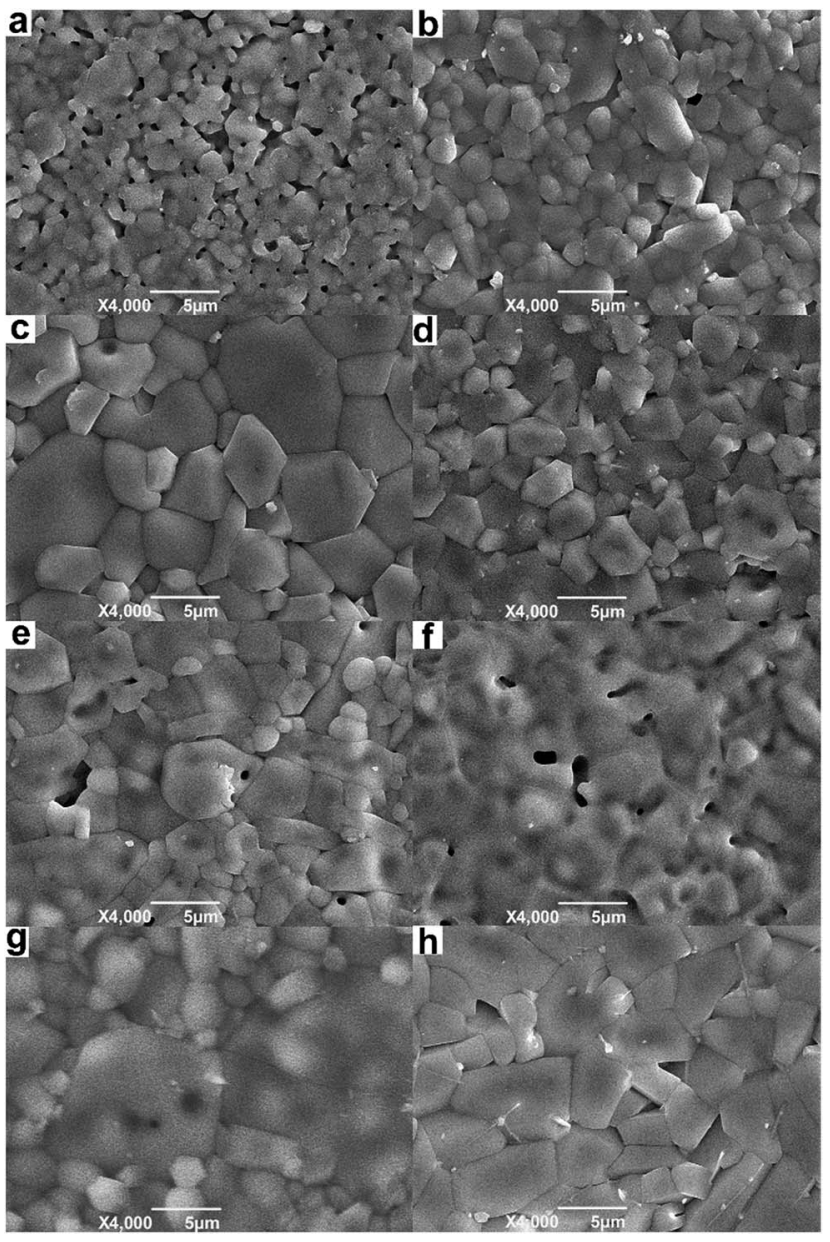

Fig. 3 SEM micrographs of $\mathrm{Li}_{2 x}\left(\mathrm{Zn}_{0.95} \mathrm{CO}_{0.05}\right)_{2-x} \mathrm{SiO}_{4}(0 \leq x \leq 1)$ ceramics doped with $1.5 \mathrm{wt} \%$ LMZBS and sintered at $900{ }^{\circ} \mathrm{C}$ for $3 \mathrm{~h}$. (a) $x=0$, (b) $x=0.125$, (c) $x=0.25$, (d) $x=0.375$, (e) $x=0.5$, (f) $x=0.625$, (g) $x=0.75$, and (h) $x=1$.

resulted in excessive liquid phase. When $x=0.75$, a dense microstructure reappeared; however, the abnormal growth grain with closed pores and the liquid phase were still observed in Fig. $3 g$. When $x$ was increased to 1 , the shape of grains became rectangular, and the intergranular pores increased (Fig. 3h). This outcome is attributed to the formation of tetragonal structure of $\mathrm{Li}_{2} \mathrm{ZnSiO}_{4}$. The optimal content of $\mathrm{Li}^{+}$ substitution was set at 0.25 to obtain the most compact and uniform microstructure.

Fig. 4 shows the relative density as a function of $x$ value for $\mathrm{Li}_{2 x}\left(\mathrm{Zn}_{0.95} \mathrm{Co}_{0.05}\right)_{2-x} \mathrm{SiO}_{4}(0 \leq x \leq 1)$ specimens doped with 1.5 wt $\%$ LMZBS glass and sintered at $850-950{ }^{\circ} \mathrm{C}$ for $3 \mathrm{~h}$. The relative density was calculated using the formula $\rho_{\mathrm{r}}=\frac{\rho}{\rho_{\mathrm{x}}}$, where $\rho$ and $\rho_{\mathrm{x}}$ are the bulk and theoretical density values, respectively. The theoretical density $\rho_{\mathrm{x}}$ was calculated as follows:

$$
\rho_{\mathrm{x}}=\left(w_{1}+w_{2}+w_{3}\right) /\left(\frac{w_{1}}{\rho_{\mathrm{x} 1}}+\frac{w_{2}}{\rho_{\mathrm{x} 2}}+\frac{w_{3}}{\rho_{\mathrm{x} 3}}\right)
$$

where $w_{1}, w_{2}$ and $w_{3}$ are the weight percentages of crystalline phases and LMZBS glass in $\mathrm{Li}_{2 x}\left(\mathrm{Zn}_{0.95} \mathrm{Co}_{0.05}\right)_{2-x} \mathrm{SiO}_{4}(0 \leq x \leq 1)$ 


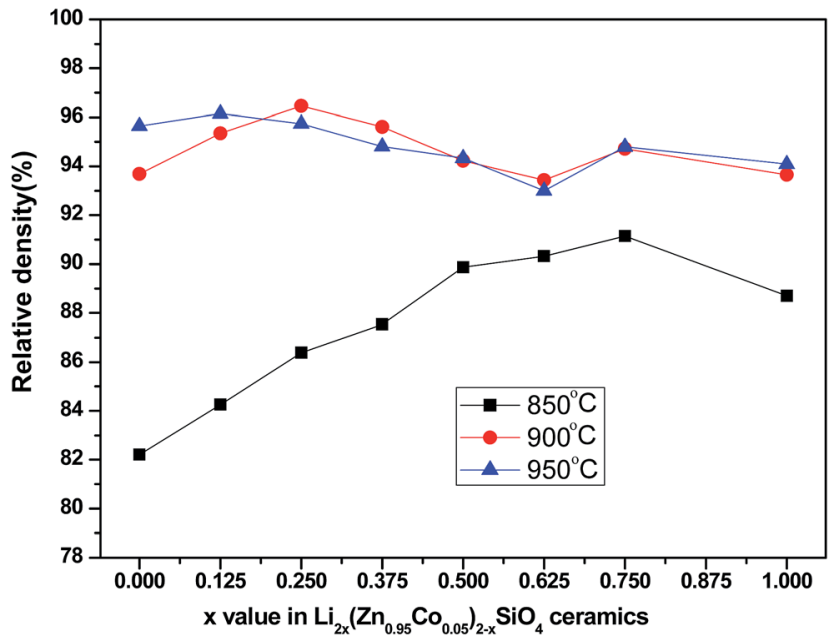

Fig. 4 Relative density of $\mathrm{Li}_{2 x}\left(\mathrm{Zn}_{0.95} \mathrm{CO}_{0.05}\right)_{2-x} \mathrm{SiO}_{4}(0 \leq x \leq 1)$ ceramics doped with $1.5 \mathrm{wt} \% \mathrm{LMZBS}$ glass and sintered at $850-950^{\circ} \mathrm{C}$ for $3 \mathrm{~h}$.

ceramics, respectively. The weight percentages of crystalline phases and LMZBS glass were obtained from the XRD analysis and were set at $1.5 \mathrm{wt} \%$. Here, $2.75 \mathrm{~g} \mathrm{~cm}^{-3}$ was used as the theoretical density of LMZBS glass. ${ }^{22}$

The relative density values of samples sintered at $900{ }^{\circ} \mathrm{C}$ generally exceed 93\%, which implies that $1.5 \mathrm{wt} \%$ LMZBS is sufficient to obtain the liquid-phase sintering necessary for the relative densification at $900{ }^{\circ} \mathrm{C}$. When a small amount of lithium was doped to the sample sintered at $900{ }^{\circ} \mathrm{C}$, the relative density increased to $96.46 \%$, which is a fairly high densification. This outcome indicates that a moderate amount of lithiumsubstitution help facilitate densification. The tendency of relative density of these samples sintered at $900{ }^{\circ} \mathrm{C}$ is also consistent with the variations in the microstructure. The relative densities of specimens sintered at $850{ }^{\circ} \mathrm{C}$ were significantly lower than those sintered at $900{ }^{\circ} \mathrm{C}$ and $950{ }^{\circ} \mathrm{C}$. This phenomenon is attributed to two reasons. One reason is the tight relationship between the sintering temperature and relative density. ${ }^{23}$ The other reason is that the softening temperature of LMZBS is around $900{ }^{\circ} \mathrm{C}$, which is higher than the sintering temperature of these samples. ${ }^{22}$ Furthermore, a lower sintering temperature shifts the obtainable maximum relative density to higher lithium doped content. This outcome suggested that the substitution of lithium ions markedly lowers the sintering temperature of the ceramics with nominal composition $\mathrm{Li}_{2 x}\left(\mathrm{Zn}_{0.95} \mathrm{Co}_{0.05}\right)_{2-x} \mathrm{SiO}_{4}$.

Fig. 5 shows the relative permittivity $\left(\varepsilon_{\mathrm{r}}\right)$ values of the $\mathrm{Li}_{2 x}$ $\left(\mathrm{Zn}_{0.95} \mathrm{Co}_{0.05}\right)_{2-x} \mathrm{SiO}_{4}(0 \leq x \leq 1)$ ceramics doped with $1.5 \mathrm{wt} \%$ LMZBS glass and sintered at $850-950{ }^{\circ} \mathrm{C}$ for $3 \mathrm{~h}$. The variation in relative permittivity of specimens sintered at $850-950{ }^{\circ} \mathrm{C}$ is generally in agreement with the trend of the relative density. Densification plays a crucial role in determining the relative permittivity. ${ }^{24}$ The $\varepsilon_{\mathrm{r}}$ of $\mathrm{Li}_{2 x}\left(\mathrm{Zn}_{0.95} \mathrm{Co}_{0.05}\right)_{2-x} \mathrm{SiO}_{4}(0 \leq x \leq 1)$ ceramics sintered at $900{ }^{\circ} \mathrm{C}$ increased with the increasing $x$ value, reached a maximum value (6.47) at $x=0.25$ and then decreased to a minimum value $(5.84)$ at $x=1$. The relative

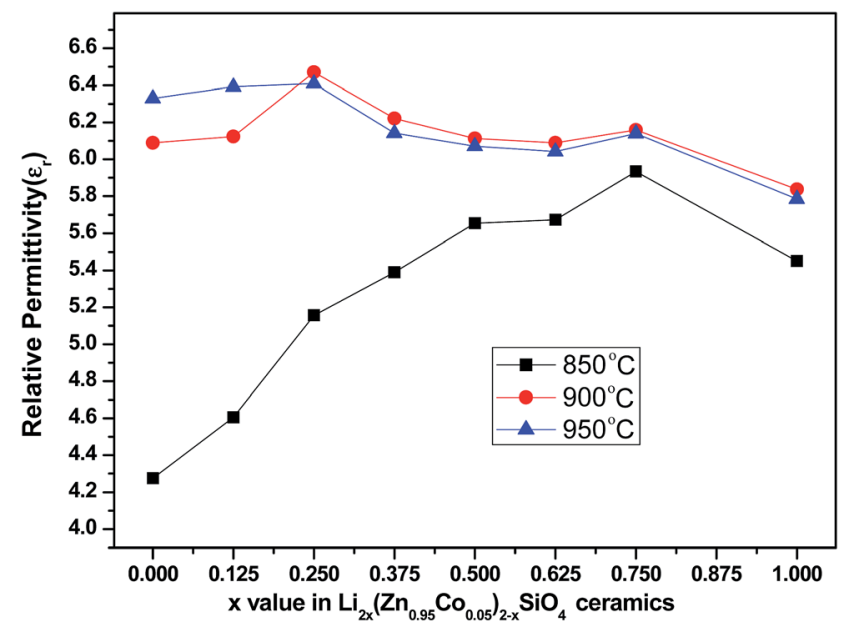

Fig. 5 Relative permittivity $\left(\varepsilon_{\mathrm{r}}\right)$ of $\mathrm{Li}_{2 x}\left(\mathrm{Zn}_{0.95} \mathrm{Co}_{0.05}\right)_{2-x} \mathrm{SiO}_{4}(0 \leq x \leq 1)$ ceramics doped with 1.5 wt\% LMZBS glass and sintered at $850-950{ }^{\circ} \mathrm{C}$ for $3 \mathrm{~h}$.

density of the sample sintered at $900{ }^{\circ} \mathrm{C}(93.69 \%)$ when $x=0$ is similar to that of the sample sintered at the same temperature (93.66\%) when $x=1$, whereas the $\varepsilon_{\mathrm{r}}$ when $x=0$ was obviously higher than when $x=1$ (6.09 and 5.83, respectively). Combined with the XRD patterns shown in Fig. 2a, this finding is due to the synthesis of $\mathrm{Li}_{2} \mathrm{ZnSiO}_{4}$, which exists as the major phase. The $\varepsilon_{\mathrm{r}}$ of $\mathrm{Li}_{2} \mathrm{ZnSiO}_{4}$ is 5.8 , which is lower than that of $\left(\mathrm{Zn}_{0.95^{-}}\right.$ $\left.\mathrm{Co}_{0.05}\right)_{2} \mathrm{SiO}_{4}(6.16) .^{12,20}$

Fig. 6 shows the variations in $Q \times f$ values of $\mathrm{Li}_{2 x}\left(\mathrm{Zn}_{0.95^{-}}\right.$ $\left.\mathrm{Co}_{0.05}\right)_{2-x} \mathrm{SiO}_{4}(0 \leq x \leq 1)$ ceramics with different $x$ contents doped with $1.5 \mathrm{wt} \%$ LMZBS and sintered at $850-950{ }^{\circ} \mathrm{C}$ for $3 \mathrm{~h}$. The variations in $Q \times f$ values are generally consistent with the variations in the relative density of $\mathrm{Li}_{2 x}\left(\mathrm{Zn}_{0.95} \mathrm{Co}_{0.05}\right)_{2-x} \mathrm{SiO}_{4}(0$ $\leq x \leq 1)$ ceramics. The $Q \times f$ values were all low when the samples were sintered at $850{ }^{\circ} \mathrm{C}$ (less than $49000 \mathrm{GHz}$ ), which is mainly attributed to the low relative densities. When the sintering temperature was increased to $900{ }^{\circ} \mathrm{C}$, the $Q \times f$ values

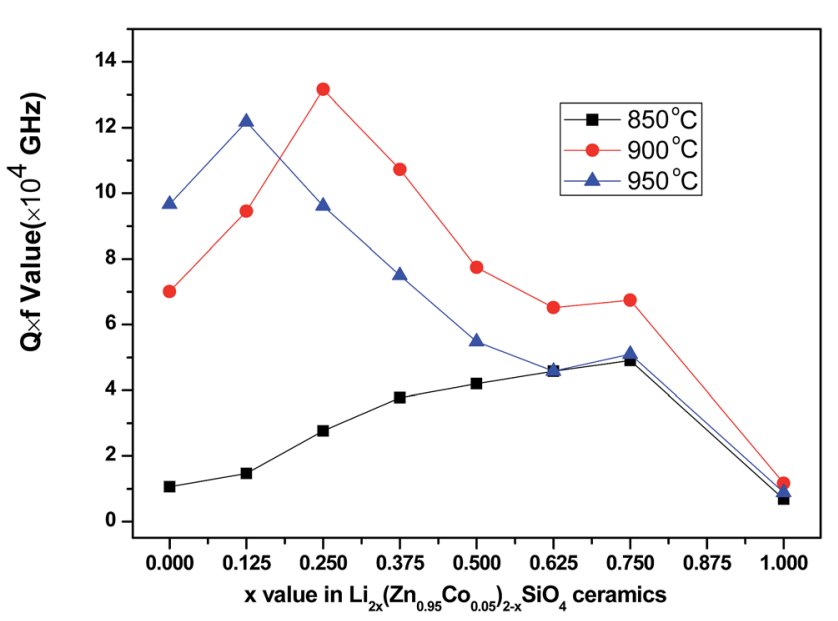

Fig. $6 Q \times f$ values of $\mathrm{Li}_{2 x}\left(\mathrm{Zn}_{0.95} \mathrm{CO}_{0.05}\right)_{2-x} \mathrm{SiO}_{4}(0 \leq x \leq 1)$ ceramics with the addition of $1.5 \mathrm{wt} \%$ LMZBS glass sintered at $850-950{ }^{\circ} \mathrm{C}$ for $3 \mathrm{~h}$. 
increased with the increasing $x$ value and achieved the maximum of $131579 \mathrm{GHz}$ at $x=0.25$. This outcome might be due to the high densification (96.46\%) of the sintered sample when $x=0.25$. According to the SEM images shown in Fig. 3c, the large grain resulted in less grain boundary, which indicates less lattice mismatch and lower dielectric loss. ${ }^{25}$ The $Q \times f$ values of the samples sintered at 850-950 ${ }^{\circ} \mathrm{C}$ remarkably decreased to the minimal values of around $6800 \mathrm{GHz}$ with the variation in $x$ from 0.75 to 1 . Microwave dielectric loss can be divided into intrinsic and extrinsic losses. ${ }^{26}$ Intrinsic losses are mainly dependent on the crystal structure and are usually caused by the lattice vibration modes. ${ }^{27}$ According to the XRD analysis shown in Fig. 2a, tetragonal structure $\mathrm{Li}_{2} \mathrm{ZnSiO}_{4}\left({ }^{*}, \mathrm{PDF}\right.$ $\# 15-0056)$ was the major phase of the sintered sample when $x=$ 1. In a previous study, $\mathrm{Li}_{2} \mathrm{ZnSiO}_{4}$ ceramics doped with $25 \mathrm{wt} \%$ ZB glass sintered at $950{ }^{\circ} \mathrm{C}$ exhibited a $Q \times f$ value of 10800 $\mathrm{GHz}$, which is approximated to the $Q \times f$ value in the present work. ${ }^{20}$ Hence, in addition to the influence of extrinsic losses caused by lower densification, the high intrinsic losses of $\mathrm{Li}_{2}$ $\mathrm{ZnSiO}_{4}$ thereby induced the dramatic decrease of $Q \times f$ values.

Fig. 7 shows the $\tau_{\mathrm{f}}$ values of the $\mathrm{Li}_{2 x}\left(\mathrm{Zn}_{0.95} \mathrm{Co}_{0.05}\right)_{2-x} \mathrm{SiO}_{4}(0 \leq$ $x \leq 1)$ ceramics with different $x$ values doped with $1.5 \mathrm{wt} \%$ LMZBS and sintered at $900{ }^{\circ} \mathrm{C}$ for $3 \mathrm{~h}$. The $\tau_{\mathrm{f}}$ values initially increased and then decreased with the increasing $x$ content. The temperature coefficient of composite ceramics was obtained from the following logarithmic rule: ${ }^{28}$

$$
\tau_{\mathrm{f}}=v_{1} \tau_{\mathrm{f} 1}+v_{2} \tau_{\mathrm{f} 2}
$$

where $\tau_{\mathrm{f} 1}$ and $\tau_{\mathrm{f} 2}$ are the $\tau_{\mathrm{f}}$ values of the $\left(\mathrm{Zn}_{0.95} \mathrm{Co}_{0.05}\right)_{2} \mathrm{SiO}_{4}$ and $\mathrm{Li}_{1.6} \mathrm{Zn}_{1.2} \mathrm{SiO}_{4}$, respectively. The $\tau_{\mathrm{f}}$ value of the sample, whose main crystalline phase was the phase of $\mathrm{Li}_{1.6} \mathrm{Zn}_{1.2} \mathrm{SiO}_{4}$ (when $x=$ 0.75), was $-9.04 \mathrm{ppm}{ }^{\circ} \mathrm{C}^{-1}$; while the $\tau_{\mathrm{f}}$ value of $\left(\mathrm{Zn}_{0.95^{-}}\right.$ $\left.\mathrm{Co}_{0.05}\right)_{2} \mathrm{SiO}_{4}$ was $-51.54 \mathrm{ppm}{ }^{\circ} \mathrm{C}^{-1}$. Hence, the $\tau_{\mathrm{f}}$ value of $\mathrm{Li}_{1.6^{-}}$ $\mathrm{Zn}_{1.2} \mathrm{SiO}_{4}$ was higher than that of $\left(\mathrm{Zn}_{0.95} \mathrm{Co}_{0.05}\right)_{2} \mathrm{SiO}_{4}$. Combined with the XRD patterns shown in Fig. $2 \mathrm{a}$ and function (3), the volume percentage of $\mathrm{Li}_{1.6} \mathrm{Zn}_{1.2} \mathrm{SiO}_{4}$ gradually increased by increasing $x$ to 0.75 , which might be the reason for the increase

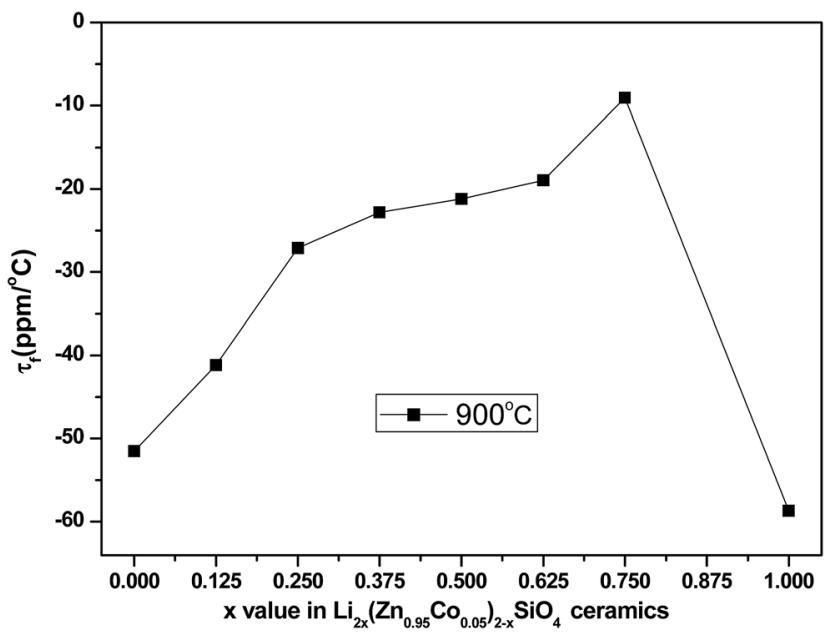

Fig. $7 \tau_{f}$ values of $\mathrm{Li}_{2 x}\left(\mathrm{Zn}_{0.95} \mathrm{CO}_{0.05}\right)_{2-x} \mathrm{SiO}_{4}(0 \leq x \leq 1)$ ceramics doped with $1.5 \mathrm{wt} \%$ LMZBS glass and sintered at $900^{\circ} \mathrm{C}$ for $3 \mathrm{~h}$. of the $\tau_{\mathrm{f}}$ values of composite ceramics when $0 \leq x \leq 0.75$. Analogously, when the $\tau_{\mathrm{f}}$ values of $\mathrm{Li}_{2} \mathrm{ZnSiO}_{4}$ was $-96.6 \mathrm{ppm}$ ${ }^{\circ} \mathrm{C}^{-1}$, the $\tau_{\mathrm{f}}$ values of $\mathrm{Li}_{2 x}\left(\mathrm{Zn}_{0.95} \mathrm{Co}_{0.05}\right)_{2-x} \mathrm{SiO}_{4}(0.75 \leq x \leq 1)$ ceramics decreased with the excessive $x$ content. ${ }^{20}$

Considering the above-mentioned analysis, the optimal $x$ value was set at 0.25 because of the best quality factor of $\mathrm{Li}_{0.5}\left(\mathrm{Zn}_{0.95} \mathrm{Co}_{0.05}\right)_{1.75} \mathrm{SiO}_{4}$. One of the most important dielectric properties when considering the practical applications for LTCC is the near-zero temperature coefficient of the resonant frequency $\left(\tau_{\mathrm{f}}\right){ }^{29}$ Large positive $\tau_{\mathrm{f}}$ of $\mathrm{CaTiO}_{3}\left(+859 \mathrm{ppm}^{\circ} \mathrm{C}^{-1}\right)$ was used as a modifier and was added into $\mathrm{Li}_{0.5}\left(\mathrm{Zn}_{0.95} \mathrm{Co}_{0.05}\right)_{1.75} \mathrm{SiO}_{4}$ powders doped with $1.5 \mathrm{wt} \%$ LMZBS to further adjust the $\tau_{\mathrm{f}}$ value $\left(-27.12 \mathrm{ppm}^{\circ} \mathrm{C}^{-1}\right)$ to around $0 \mathrm{ppm}^{\circ} \mathrm{C}^{-1}$. The five weight percentages of $\mathrm{CaTiO}_{3}$ were calculated by using the logarithmic rule, where the $\tau_{\mathrm{f}}$ value of $\mathrm{Li}_{0.5}\left(\mathrm{Zn}_{0.95} \mathrm{Co}_{0.05}\right)_{1.75} \mathrm{SiO}_{4}$ was set at $-15,-21,-27,-33$ and $-39 \mathrm{ppm}^{\circ} \mathrm{C}^{-1}$.

Fig. 8 presents the $\mathrm{X}$-ray diffraction patterns of $(1-x)$ $\mathrm{Li}_{0.5}\left(\mathrm{Zn}_{0.95} \mathrm{Co}_{0.05}\right)_{1.75} \mathrm{SiO}_{4}-x$ wt\% $\mathrm{CaTiO}_{3}$ ceramics doped with $1.5 \mathrm{wt} \%$ LMZBS and sintered at $900{ }^{\circ} \mathrm{C}$ for $3 \mathrm{~h}$. All the samples exhibited the mixture of $(\mathrm{Zn}, \mathrm{Co})_{2} \mathrm{SiO}_{4}$ (, PDF \#46-1316), $\mathrm{Li}_{1.6} \mathrm{Zn}_{1.2} \mathrm{SiO}_{4}\left(\diamond, \mathrm{PDF}\right.$ \#24-0676) and $\mathrm{CaTiO}_{3}(\nabla, \mathrm{PDF}$ \#390145) phases, which indicated that the $\mathrm{CaTiO}_{3}$ phase co-exists with the $\mathrm{Li}_{0.5}\left(\mathrm{Zn}_{0.95} \mathrm{Co}_{0.05}\right)_{1.75} \mathrm{SiO}_{4}$ ceramic. Furthermore, no other new phase was produced during sintering.

Fig. 9 shows the theoretical and measured $\tau_{\mathrm{f}}$ values of $(1-x)$ $\mathrm{Li}_{0.5}\left(\mathrm{Zn}_{0.95} \mathrm{Co}_{0.05}\right)_{1.75} \mathrm{SiO}_{4}-x$ wt\% $\mathrm{CaTiO}_{3}$ ceramics doped with $1.5 \mathrm{wt} \%$ LMZBS and sintered at $900{ }^{\circ} \mathrm{C}$ for $3 \mathrm{~h}$. The theoretical $\tau_{\mathrm{f}}$ values of $(1-x) \mathrm{Li}_{0.5}\left(\mathrm{Zn}_{0.95} \mathrm{Co}_{0.05}\right)_{1.75} \mathrm{SiO}_{4}-x \quad$ wt\% $\quad \mathrm{CaTiO}_{3}$ composite ceramics were calculated using the function (3). As seen in Fig. 9, the theoretical $\tau_{\mathrm{f}}$ value of the sample increased with the increasing $\mathrm{CaTiO}_{3}$ content, which resulted from the high $\tau_{\mathrm{f}}$ value of $\mathrm{CaTiO}_{3}{ }^{23}$ The change in the measured $\tau_{\mathrm{f}}$ values showed a similar tendency with the theoretical values, which indicated that the addition of $\mathrm{CaTiO}_{3}$ shifts the $\tau_{\mathrm{f}}$ values of $\mathrm{Li}_{0.5}\left(\mathrm{Zn}_{0.95} \mathrm{Co}_{0.05}\right)_{1.75} \mathrm{SiO}_{4}$ ceramics to positive values. When the

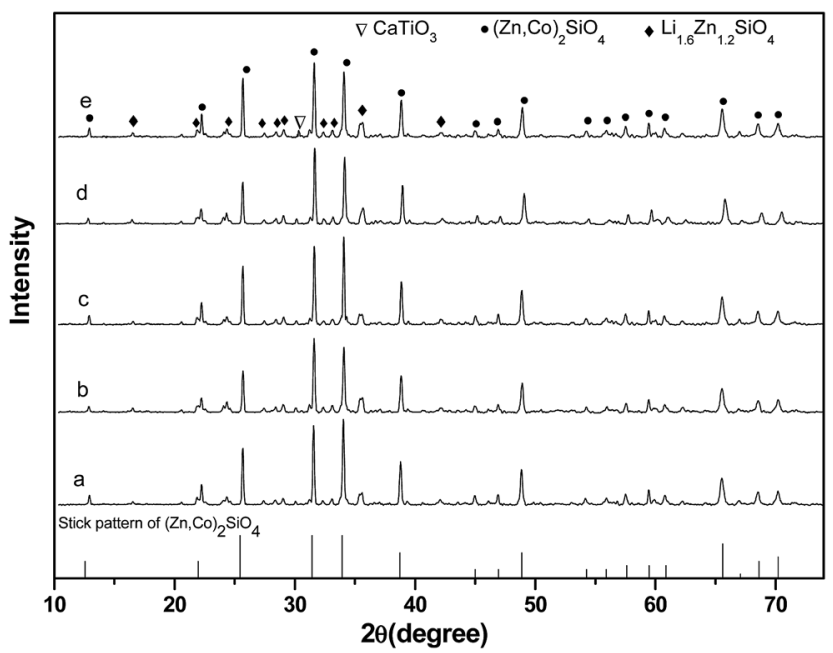

Fig. 8 XRD diffraction patterns of $(1-x) \mathrm{Li}_{0.5}\left(\mathrm{Zn}_{0.95} \mathrm{CO}_{0.05}\right)_{1.75} \mathrm{SiO}_{4}-x$ wt\% $\mathrm{CaTiO}_{3}$ ceramics doped with $1.5 \mathrm{wt} \%$ LMZBS and sintered at $900{ }^{\circ} \mathrm{C}$ for 3 h. (a) $x=1.79$, (b) $x=2.49$, (c) $x=3.18$, (d) $x=3.86$ and (e) $x$ $=4.53$. 


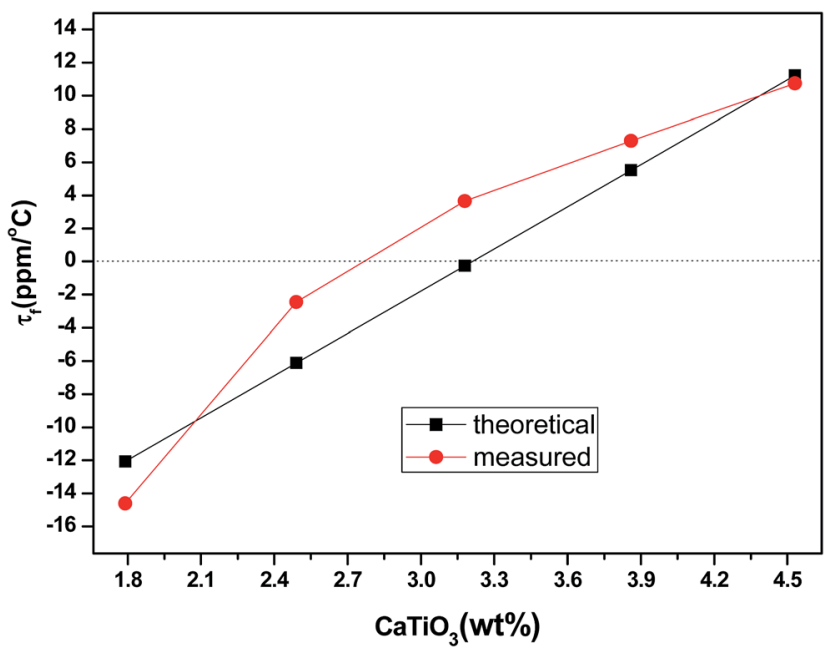

Fig. 9 Theoretical and measured $\tau_{f}$ values of $(1-x) \mathrm{Li}_{0.5}\left(\mathrm{Zn}_{0.95}\right.$ $\left.\mathrm{CO}_{0.05}\right)_{1.75} \mathrm{SiO}_{4}-x$ wt\% $\mathrm{CaTiO}_{3}$ ceramics doped with 1.5 wt\% LMZBS and sintered at $900{ }^{\circ} \mathrm{C}$ for $3 \mathrm{~h}$.

weight percentage of $\mathrm{CaTiO}_{3}$ increased from 1.79 wt $\%$ to 4.53 wt $\%$, the measured $\tau_{\mathrm{f}}$ values increased from $-14.6 \mathrm{ppm}{ }^{\circ} \mathrm{C}^{-1}$ to $10.74 \mathrm{ppm}{ }^{\circ} \mathrm{C}^{-1}$. A near-zero $\tau_{\mathrm{f}}$ value $\left(-2.45 \mathrm{ppm}{ }^{\circ} \mathrm{C}^{-1}\right)$ was obtained when $x=2.49 \mathrm{wt} \%$ and the ceramic was sintered at $900{ }^{\circ} \mathrm{C}$ for $3 \mathrm{~h}$.

Table 1 shows the theoretical and measured microwave dielectric properties of $(1-x) \mathrm{Li}_{0.5}\left(\mathrm{Zn}_{0.95} \mathrm{Co}_{0.05}\right)_{1.75} \mathrm{SiO}_{4}-x$ wt $\%$ $\mathrm{CaTiO}_{3}$ ceramics doped with $1.5 \mathrm{wt} \%$ LMZBS and sintered at $900{ }^{\circ} \mathrm{C}$ for $3 \mathrm{~h}$. The theoretical permittivities of the composite ceramics were calculated using the function below: ${ }^{30}$

$$
\log \varepsilon=v_{1} \log \varepsilon_{1}+v_{2} \log \varepsilon_{2}
$$

where $v_{1}$ and $v_{2}$ are the volume fractions and $\varepsilon_{1}$ and $\varepsilon_{2}$ are the relative permittivities of the $\mathrm{Li}_{0.5}\left(\mathrm{Zn}_{0.95} \mathrm{Co}_{0.05}\right)_{1.75} \mathrm{SiO}_{4}$ and $\mathrm{CaTiO}_{3}$ ceramics, respectively. Table 1 shows that the variation of the measured $\varepsilon_{\mathrm{r}}$ of $(1-x) \mathrm{Li}_{0.5}\left(\mathrm{Zn}_{0.95} \mathrm{Co}_{0.05}\right)_{1.75} \mathrm{SiO}_{4}-x$ wt $\%$ $\mathrm{CaTiO}_{3}$ composite ceramics agrees well with the theoretical value. Given the relatively high $\varepsilon_{\mathrm{r}}$ of $\mathrm{CaTiO}_{3}(162)$, the measured value increased from 6.47 to 7.152 when the $x$ value increased from $0 \mathrm{wt} \%$ to $4.53 \mathrm{wt} \%$. Analogously, the $Q \times f$ values of $(1-x)$ $\mathrm{Li}_{0.5}\left(\mathrm{Zn}_{0.95} \mathrm{Co}_{0.05}\right)_{1.75} \mathrm{SiO}_{4}-x$ wt\% $\mathrm{CaTiO}_{3}$ composite ceramics decreased from $131579 \mathrm{GHz}$ to $41344 \mathrm{GHz}$ with the increasing

Table 1 Theoretical and measured microwave dielectric properties of the $(1-x) \mathrm{Li}_{0.5}\left(\mathrm{Zn}_{0.95} \mathrm{Co}_{0.05}\right)_{1.75} \mathrm{SiO}_{4}-x$ wt\% $\mathrm{CaTiO}_{3}$ ceramics doped with $1.5 \mathrm{wt} \% \mathrm{LMZBS}$ and sintered at $900{ }^{\circ} \mathrm{C}$ for $3 \mathrm{~h}$

\begin{tabular}{llll}
\hline & $\begin{array}{l}\varepsilon_{\mathrm{r}} \\
\text { (theoretical) }\end{array}$ & $\begin{array}{l}\varepsilon_{\mathrm{r}} \\
\text { (measured) }\end{array}$ & $\begin{array}{l}Q \times \\
f \text { values }(\mathrm{GHz})\end{array}$ \\
\hline$x=0$ & & 6.47 & 131579 \\
$x=1.79$ & 6.838 & 6.578 & 74584 \\
$x=2.49$ & 6.987 & 6.773 & 69177 \\
$x=3.18$ & 7.137 & 6.936 & 57296 \\
$x=3.86$ & 7.289 & 7.015 & 51782 \\
$x=4.53$ & 7.441 & 7.152 & 41344
\end{tabular}

$x$ content. This finding is attributed to the low $Q \times f$ value of $\mathrm{CaTiO}_{3}(12000 \mathrm{GHz}){ }^{23}$ Although $\mathrm{CaTiO}_{3}$ adjusted the $\tau_{\mathrm{f}}$ values of the $\mathrm{Li}_{0.5}\left(\mathrm{Zn}_{0.95} \mathrm{Co}_{0.05}\right)_{1.75} \mathrm{SiO}_{4}$ ceramics to nearly zero, the $Q \times$ $f$ values sharply decreased when $\mathrm{CaTiO}_{3}$ was added.

\section{Conclusion}

The phase evolution and microwave dielectric properties of ceramics with nominal composition $\mathrm{Li}_{2 x}\left(\mathrm{Zn}_{0.95} \mathrm{Co}_{0.05}\right)_{2-x} \mathrm{SiO}_{4}$ were investigated. Lithium ions were added to partly substitute for the zinc ions, and a fixed amount of $1.5 \mathrm{wt} \%$ LMZBS glass was used as a sintering aid to help lower the sintering temperature of $\mathrm{Li}_{2 x}\left(\mathrm{Zn}_{0.95} \mathrm{Co}_{0.05}\right)_{2-x} \mathrm{SiO}_{4}(0 \leq x \leq 1)$ ceramics of around $900{ }^{\circ} \mathrm{C}$. The XRD patterns indicated that various amounts of lithium-ion substitution induce different production patterns of other phases in the $\mathrm{Li}_{2 x}\left(\mathrm{Zn}_{0.95} \mathrm{Co}_{0.05}\right)_{2-x} \mathrm{SiO}_{4}(0 \leq x \leq 1)$ ceramics. A compact and uniform microstructure with few pores, high relative density and $Q \times f$ value was obtained when $x$ was set at 0.25 . The sample exhibited excellent microwave dielectric properties of $\varepsilon_{\mathrm{r}}=6.47, Q \times f=131579 \mathrm{GHz}$ and $\tau_{\mathrm{f}}=$ $-27.12 \mathrm{ppm}{ }^{\circ} \mathrm{C}^{-1}$. In considering the practical application for LTCC, a positive $\tau_{\mathrm{f}}$ of $\mathrm{CaTiO}_{3}$ was used to adjust the $\tau_{\mathrm{f}}$ value of the composite ceramics to nearly zero. The $1.5 \mathrm{wt} \%$ LMZBSdoped $0.975 \quad \mathrm{Li}_{0.5}\left(\mathrm{Zn}_{0.95} \mathrm{Co}_{0.05}\right)_{1.75} \mathrm{SiO}_{4}-0.025 \mathrm{CaTiO}_{3}$ (weight ratio) composite ceramics also presented good dielectric properties of $\varepsilon_{\mathrm{r}}=6.773, Q \times f=69177 \mathrm{GHz}$ and $\tau_{\mathrm{f}}=-2.45 \mathrm{ppm}$ ${ }^{\circ} \mathrm{C}^{-1}$.

\section{Acknowledgements}

This work was supported by the National Natural Science Foundation of China under Grant No. 51372031, 61271038 and 51472042, National High-tech R\&D Program of China under Grant No. 2015AA034102, Special Support Program of Guangdong Province under Grant No. 2014TX01C042 and Science and Technology Department of Sichuan Province 2014GZ0015, $2015 G Z 0227$.

\section{References}

1 W. Lei, W.-Z. Lu, D. Liu and J.-H. Zhu, J. Am. Ceram. Soc., 2009, 92, 105-109.

2 Y. Zhao and P. Zhang, RSC Adv., 2015, 5, 97746-97754.

3 T. Tsunooka, M. Androu, Y. Higashida, H. Sugiura and H. Ohsato, J. Eur. Ceram. Soc., 2003, 23, 2573-2578.

4 O. Yoshihiro, M. Yasuharu, O. Hitoshi and K. Ken-ichi, Jpn. J. Appl. Phys., 2004, 43, L749.

5 J. C. Kim, M.-H. Kim, S. Nahm, J.-H. Paik, J.-H. Kim and H.-J. Lee, J. Eur. Ceram. Soc., 2007, 27, 2865-2870.

6 H. Li, W. Lu and W. Lei, Mater. Lett., 2012, 71, 148-150.

7 J. Guo, D. Zhou, H. Wang and X. Yao, J. Alloys Compd., 2011, 509, 5863-5865.

8 V. M. Ferreira, F. Azough, J. L. Baptista and R. Freer, Ferroelectrics, 1992, 133, 127-132.

9 Z. Zhang, H. Su, X. L. Tang, H. W. Zhang, T. C. Zhou and Y. L. Jing, Ceram. Int., 2014, 40, 1613-1617. 
10 Y. Guo, H. Ohsato and K.-i. Kakimoto, J. Eur. Ceram. Soc., 2006, 26, 1827-1830.

11 H. W. Chen, H. Su, H. W. Zhang, T. C. Zhou, B. W. Zhang, J. F. Zhang and X. L. Tang, Ceram. Int., 2014, 40, 1465514659.

12 Z. H. Zhou, H. Su, X. L. Tang, H. W. Zhang, F. Xu, S. Zhang and Y. L. Jing, Ceram. Int., 2016, 42, 11161-11164.

13 J.-j. Bian, D.-W. Kim and K. S. Hong, Mater. Res. Bull., 2005, 40, 2120-2129.

14 S. George, M. T. Sebastian, S. Raman and P. Mohanan, Int. J. Appl. Ceram. Technol., 2011, 8, 172-179.

15 S.-H. Kweon, M.-R. Joung, J.-S. Kim, B.-Y. Kim, S. Nahm, J.-H. Paik, Y.-S. Kim and T.-H. Sung, J. Am. Ceram. Soc., 2011, 94, 1995-1998.

16 S. George, P. S. Anjana, V. N. Deepu, P. Mohanan and M. T. Sebastian, J. Am. Ceram. Soc., 2009, 92, 1244-1249.

17 E. D. Kim, C. H. Kim and M. H. Oh, J. Appl. Phys., 1985, 58, 3231-3235.

18 X. C. Fan, X. M. Chen and X. Q. Liu, IEEE Trans. Microwave Theory Tech., 2005, 53, 3130-3134.

19 Z. Q. Yuan, B. Liu, X. Q. Liu and X. M. Chen, $R S C A d v ., 2016$, 6, 96229-96236.
20 G. Dou, D. Zhou, S. Gong and M. Guo, J. Mater. Sci.: Mater. Electron., 2012, 24, 1601-1607.

21 Q. Zeng, W. Li, J.-l. Shi, J.-k. Guo, M.-w. Zuo and W.-j. Wu, J. Am. Ceram. Soc., 2006, 89, 1733-1735.

22 P. S. Anjana and M. T. Sebastian, J. Am. Ceram. Soc., 2009, 92, 96-104.

23 C.-H. Hsu, P.-S. Tsai, C.-F. Tseng, S.-H. Hung and I. C. Huang, J. Alloys Compd., 2014, 582, 355-359.

24 H. L. Pan, Q. Q. Liu, Y. H. Zhang and H. T. Wu, RSC Adv., 2016, 6, 86889-86903.

25 X. Lu, Y. Zheng, B. Zhou, Z. Dong and P. Cheng, Ceram. Int., 2013, 39, 9829-9833.

26 H.-H. Xi, D. Zhou, B. He, H.-D. Xie and N. Alford, J. Am. Ceram. Soc., 2014, 97, 1375-1378.

27 C. Tian, Z. Yue and Y. Zhou, Mater. Sci. Eng., B, 2013, 178, 178-182.

28 B. W. Hakki and P. D. Coleman, IRE Trans. Microwave Theory Tech., 1960, 8, 402-410.

29 M. Guo, G. Dou, S. Gong and D. Zhou, J. Eur. Ceram. Soc., 2012, 32, 883-890.

30 Y. Wu, X. Zhao, F. Li and Z. Fan, J. Electroceram., 2003, 11, 227-239. 